\title{
A CLOZAPINE-LIKE EFFECT OF CYPROHEPTADINE ON PROGRESSIVE-RATIO SCHEDULE PERFORMANCE
}

\author{
C.M. Olarte Sanchez, L. Valencia Torres, S. Body, H.J. Cassaday, \\ C.M. Bradshaw, E. Szabadi \& A.J.Goudie ${ }^{2}$
}

Psychopharmacology Section, Division of Psychiatry, and ${ }^{1}$ School of Psychology, University of Nottingham

and

${ }^{2}$ School of Psychology, University of Liverpool

Correspondence:

C.M. Bradshaw

Psychopharmacology Section

Division of Psychiatry

University of Nottingham

Room B109, Medical School

Queen's Medical Centre

Nottingham, NG7 2UH

UK

e-mail: $\quad$ c.m.bradshaw@ nottingham.ac.uk

telephone: $\quad+44(0) 1158230221$

fax: $\quad+44(0) 1158230220$

\section{Sources of support}

This work was funded by the Schools of Community Health Science and Psychology, University of Nottingham, and the School of Psychology, University of Liverpool. CMOS was supported by an MRC/DTA PhD studentship. LVT was supported by a PhD studentship awarded by the National Science Council of Mexico (CONACYT) 
Abstract. The atypical antipsychotic drug clozapine has multiple pharmacological actions, some of which, including 5-hydroxytryptamine $\left(5-\mathrm{HT}_{2}\right)$ and histamine $\left(\mathrm{H}_{1}\right)$ receptor antagonist effects, are shared by the non-selective 5-HT receptor antagonist cyproheptadine. Atypical antipsychotics have a characteristic profile of action on operant behaviour maintained by progressive-ratio schedules, as revealed by Killeen's (1994) mathematical model of scheduled controlled behaviour. These drugs increase the values of a parameter that expresses the 'incentive value' of the reinforcer $(a)$ and a parameter that is inversely related to the 'motor capacity' of the organism $(\delta)$. This experiment examined the effects of acute treatment with cyproheptadine and clozapine on performance on a progressive-ratio schedule of food reinforcement in rats; the effects of a conventional antipsychotic, haloperidol, and two drugs with food intake-enhancing effects, chlordiazepoxide and $\Delta^{9}$-tetrahydrocannabinol (THC), were also examined. Cyproheptadine $\left(1,5 \mathrm{mg} \mathrm{kg}^{-1}\right)$ and clozapine $\left(3.75,7.5 \mathrm{mg} \mathrm{kg}^{-1}\right)$ increased $a$ and $\delta$. Haloperidol $\left(0.05,0.1 \mathrm{mg} \mathrm{kg}^{-1}\right)$ reduced $a$ and increased $\delta$. Chlordiazepoxide $\left(3,10 \mathrm{mg} \mathrm{kg}^{-1}\right)$ increased $a$ but reduced $\delta$. THC $\left(1,3 \mathrm{mg} \mathrm{kg}^{-1}\right)$ had no effect. Interpretation based on Killeen's (1994) model suggests that cyproheptadine and clozapine enhanced the incentive value of the reinforcer and impaired motor performance. Motor impairment may be due to sedation (possibly reflecting $\mathrm{H}_{1}$ receptor blockade). Enhancement of incentive value may reflect simultaneous blockade of $\mathrm{H}_{1}$ and 5- $\mathrm{HT}_{2}$ receptors, which has been proposed as the mechanism underlying the food intake-enhancing effect of cyproheptadine. In agreement with previous findings, haloperidol impaired motor performance and reduced the incentive value of the reinforcer. Chlordiazepoxide's effect on $a$ is consistent with its food intake-enhancing effect. 
Keywords: progressive-ratio schedule - cyproheptadine - atypical antipsychotics - clozapine - haloperidol - chlordiazepoxide $\Delta^{9}$-tetrahydrocannabinol - reinforcer efficacy - rats 


\section{Introduction}

It is generally agreed that 'conventional' antipsychotic drugs, including the phenothiazines and butyrophenones, are less effective in combating the negative symptoms of schizophrenia (anhedonia, avolition, flattened affect) than they are in suppressing positive psychotic symptoms (hallucinations, delusions). Indeed, there is evidence that conventional antipsychotics may have an adverse effect on motivation in man, as they are known to do in animals (Wise 1982, 2006; King and Waddington 2004). In contrast, 'atypical' antipsychotics, such as clozapine, which have a lower propensity to induce extrapyramidal side-effects than conventional antipsychotics, are less liable to induce negative symptoms, and in some cases may even help to alleviate these symptoms by enhancing motivation (Müller-Spahn 2002; Corrigan et al. 2003).

An adverse effect of conventional antipsychotics on motivation in animals has been recognized for many years (Wise 1982). For example, operant behaviour maintained by food or psychostimulant self-administration is suppressed by conventional antipsychotics, and it has been proposed that this effect is caused by a reduction of the incentive value of primary reinforcers (Wise 1982, 2006). Less is known about the effects of atypical antipsychotics on motivation and reinforcement processes; however there is evidence that these drugs enhance food intake in rodents (Hartfield et al. 2003) as they do in humans (Meltzer et al. 2003), and that they may increase the incentive value of food in operant behaviour paradigms (Mobini et al. 2000; Cilia et al. 2001; Zhang et al. 2005a, 2005b; see below).

The principal pharmacological action of conventional antipsychotics is the blockade of $\mathrm{D}_{2}$ dopamine receptors (Seeman et al. 1976; Kapur et al. 2000), and it has been proposed that the adverse effects of these drugs on motivation reflect their ability to disrupt dopaminergic mechanisms in limbic structures (Wise 1982, 2006). Atypical 
antipsychotics, however, have complex and varied pharmacological profiles, and their principal mode(s) of action remain in dispute. Clozapine, the most extensively studied drug of this class, has a relatively low affinity for $\mathrm{D}_{2}$ dopamine receptors, but a high affinity for several subtypes of 5-hydroxytryptamine (5-HT) receptor, most notably 5$\mathrm{HT}_{2 \mathrm{~A}}$ receptors (Bymaster et al. 1996). The combination of $\mathrm{D}_{2}$ and 5-HT2A receptor antagonism has been proposed as the basis of clozapine's favourable therapeutic profile (Meltzer et al. 1989; Ichikawa et al. 2001), leading to the suggestion that the combination of a conventional antipsychotic with a 5- $\mathrm{HT}_{2}$ receptor antagonist might offer some therapeutic advantages over treatment with a conventional antipsychotic alone in the management of the negative symptoms of schizophrenia (Meltzer et al. 1995). Clinical investigations of this proposal have yielded mixed results: some studies found that the 5-HT receptor antagonist cyproheptadine (which also has high affinity at $\mathrm{H} 1$ receptors (Goudie et al. 2007), produced an improvement of negative symptomatology in schizophrenic patients concurrently treated with a conventional antipsychotic (Silver et al. 1989; Bacher et al. 1994; Akhondzadeh et al. 1999), whereas others found no significant effect (Silver et al. 1991; Lee et al. 1995; Chaudhry et al. 2002).

There have been several preclinical studies comparing the behavioural effects of atypical antipychotics and cyproheptadine. Comparisons of clozapine and cyproheptadine are of particular interest because these drugs have similar profiles of affinity for different subtypes of 5-HT receptor, both drugs having particularly high affinity for 5- $\mathrm{HT}_{2 \mathrm{~A}}$ and $\mathrm{H}_{1}$ receptors (Bymaster et al. 1996; Young et al. 2005; Goudie et al. 2007). These drugs share many behavioural effects. Both drugs stimulate food intake and induce weight gain, have sedative effects, and reverse the suppressant effect of punishment on operant responding in rats (Ketelaars and Bruinvels 1989; 
Moore et al. 1992; Hartfield et al. 2003). Recently it has been found that the two drugs show generalization and cross-tolerance in a drug discrimination paradigm (Goudie et al. 2007). The present experiment extended these observations by comparing the effects of clozapine and cyproheptadine on operant behaviour in rats, with the aim of establishing whether these drugs also share the ability to enhance the incentive value of a food reinforcer.

Several methods have been proposed to assess the effects of drugs on the incentive value of reinforcers. One such method is the progressive-ratio schedule, in which the number of responses required to obtain a reinforcer increases progressively with successive reinforcers (Hodos 1961; Hodos and Kalman 1963). The ratio at which the subject stops responding (the breakpoint) (Hodos 1961), or the highest ratio completed within a time-constrained session (Aberman et al. 1998; Hamill et al. 1999), has been regarded as a measure of incentive value (Hodos 1961; Cheeta et al. 1995) or the organism's motivation to obtain a reinforcer (Barr and Philips 1998). However, doubts have been raised about the use of the breakpoint as an index of incentive value (Arnold and Roberts 1997; Mobini et al. 2000; Ho et al. 2003; Killeen et al. 2009; Rickard et al. 2009). This measure is sensitive not only to changes in reinforcer value but also to non-motivational variables such as the height of the operant lever (Aberman et al. 1998; Skjoldager et al. 1993) and the ratio step size (Stafford and Branch 1998). It has also been noted that there is no consensus about the definition of the breakpoint (Arnold and Roberts 1998; Killeen et al. 2009), and reliance upon a single datum point determined by the subject's persistence in responding can be problematic in the case of drugs with short plasma half-lives (Arnold and Roberts 1997; Stafford et al. 1998; Rowlett 2000; Killeen et al. 2009). 
Quantitative models of schedule-controlled behaviour enable some of the problems related to the breakpoint to be circumvented, and may offer a more reliable basis for discriminating between the effects of drugs on incentive value and motor functions. One such model is Killeen's Mathematical Principles of Reinforcement (MPR: Killeen 1994; Killeen and Sitomer 2001). According to this model, schedulecontrolled responding is determined by three factors: a general excitatory effect of reinforcers on behaviour, a biological constraint on responding imposed by the response requirement and the physical capacities of the organism, and the efficiency with which particular reinforcement schedules couple operant responses to reinforcers. In the case of ratio schedules, in which $N$ responses are required to obtain a reinforcer, response rate, $R$, is predicted by the following equation:

$$
R=\frac{1-(1-\beta)^{N}}{\delta}-\frac{N}{a} \quad ; \quad \delta, a>0 ; 0<\beta<1
$$

where $\beta$ ('currency') represents the extent to which the strengthening effect of the reinforcer is focussed on the most recent response, $\delta$ ('response time') is the minimum time needed to execute a response, and $a$ ('specific activation') is the time for which a reinforcer is able to activate behaviour. Equation 1 defines an 'inverted- $U$ ' function. $\beta$ influences the horizontal location of the peak of the function, $\delta$ determines the height of the peak, $1 / \delta$ being the theoretical maximum response rate, and $a$ specifies the slope of the descending limb (slope $=-1 / a$ ). It has been suggested that the last of these parameters, $a$, may provide an index of reinforcer efficacy (Killeen and Sitomer 2003; Reilly 2003), a proposal that has found empirical support in demonstrations of the sensitivity of this parameter to manipulation of reinforcer size and quality (Bizo and Killeen 1997; Reilly 2003; Rickard et al. 2009). 
Equation 1 was developed to describe performance on fixed- and variable-ratio schedules; however it also provides a good description of overall response rates on progressive-ratio schedules (Ho et al. 2003; Kheramin et al. 2005; Zhang et al. 2005a, 2005b; Bezzina et al. 2008a, 2008b; Killeen et al. 2009; Rickard et al. 2009). Application of Equation 1 to progressive-ratio schedule performance has been used to detect the effects of brain lesions and centrally-acting drugs on motivational and motor-related processes (Mobini et al. 2000; Ho et al. 2003; Reilly 2003; Kheramin et al. 2005; Zhang et al. 2005a, 2005b; Bezzina et al. 2008a, 2008b).

A recent study of the effect of reinforcer size on progressive-ratio schedule performance (Rickard et al. 2009) showed that while Equation 1 provided a good description of overall response rate, its fit to the running response rate (response rate calculated after exclusion of the post-reinforcement pause) was less satisfactory. Running response rate was, however, well described by the logistic function

$$
\mathrm{R}=\mathrm{R}_{\mathrm{i}} /\left(1+[\mathrm{N} / b]^{c}\right)
$$

where $R_{i}$ is a parameter expressing the initial (maximum) response rate, $b$ expresses the rate of decay of the function, and the exponent $c$ modulates the curvature of the function. Rickard et al. (2009) found that $b$ was monotonically related to reinforcer size, while $R_{i}$ and $c$ were unaffected by changes in reinforcer size.

Atypical antipsychotics have a profile of action on the parameters of Equation 1 which distinguishes them from conventional antipsychotics. Clozapine and other atypical antipsychotics (e.g. quetiapine, olanzapine and ziprasidone) increase both $a$ and $\delta$ (Mobini et al. 2000; Zhang et al. 2005a, 2005b), consistent with an increase in the incentive value of the reinforcer and an impairment of motor function. Conventional antipsychotics (e.g., haloperidol, pimozide, raclopride and cis- 
flupenthixol) also increase $\delta$, but unlike the atypical antipsychotics they either have no effect on $a$ or reduce the value of this parameter (Mobini et al. 2000; Zhang et al. 2005a).

The present experiment compared the effects of cyproheptadine and clozapine on the parameters of Equations 1 and 2. Based on the similarity of these drugs' effects on food intake and the finding that these two drugs display behavioural crosstolerance and generalization in drug discrimination studies (see above), it was predicted that cyproheptadine, like clozapine, would increase the values of $a$ and $\delta$. For comparison, the effects of the conventional antipsychotic haloperidol and two drugs with well documented food intake-enhancing effects, chlordiazepoxide (Berridge and Treit 1986; Freet et al. 2006) and $\Delta^{9}$-tetrahydrocannabinol (THC) (Abel, 1975; Kirkham and Williams 2001; Koch 2001; Williams and Kirkham 2002), were also examined.

\section{Methods}

The experiment was carried out in accordance with UK Home Office regulations governing experiments on living animals.

\section{Subjects}

Female Wistar rats approximately 4 months old and weighing 250-300 $\mathrm{g}$ at the start of the experiment were used. They were housed under a constant cycle of $12 \mathrm{~h}$ light and $12 \mathrm{~h}$ darkness (light on $0600-1800$ hours), and were maintained at $80 \%$ of their initial free-feeding body weights throughout the experiment by providing a limited amount of standard rodent diet after each experimental session. Tap water was freely available in the home cages. 


\section{Apparatus}

The rats were trained in operant conditioning chambers (Campden Instruments Limited, Sileby, UK) of internal dimensions $20 \mathrm{~cm} \times 23 \mathrm{~cm} \times 22.5 \mathrm{~cm}$. One wall of the chamber contained a recess into which a motor-operated dispenser could deliver 45-mg food pellets (TestDiet products, formula 5TUM). An aperture was situated 5 $\mathrm{cm}$ above and $2.5 \mathrm{~cm}$ to one side of the recess (left or right, counterbalanced across rats), through which a motor-driven retractable lever could be inserted into the chamber. The lever could be depressed by a force of approximately $0.2 \mathrm{~N}$. The chamber was enclosed in a sound-attenuating chest; masking noise was provided by a rotary fan. An Acorn microcomputer programmed in Arachnid BASIC (CeNeS Ltd, Cambridge, UK), located in an adjoining room, controlled the schedules and recorded the behavioural data.

\section{Behavioural training}

Two weeks before starting the experiment, the food deprivation regimen was introduced and the rats were gradually reduced to $80 \%$ of their free-feeding body weights. Then they were trained to press the lever for the food-pellet reinforcer, and were exposed to a fixed-ratio 1 schedule for 3 days followed by fixed-ratio 5 for a further 3 days. Thereafter, they underwent daily training sessions under the progressive-ratio schedule. The progressive-ratio schedule was based on the following exponential progression: $1,2,4,6,9,12,15,20,25,32,40,50, \ldots$, derived from the formula $\left(5 \times \mathrm{e}^{0.2 n}\right)-5$, rounded to the nearest integer, where $n$ is the position in the sequence of ratios (Roberts and Richardson 1992). Sessions took place at the same time each day during the light phase of the daily cycle (between 0800 and 1300 hours) 
7 days a week. At the start of each session, the lever was inserted into the chamber; the session was terminated by withdrawal of the lever 50 min later.

\section{Drug treatment}

The drug treatment regimen started after 90 sessions of preliminary training under the progressive-ratio schedule. Injections of drugs were given on Tuesdays and Fridays, and injections of the vehicle alone on Mondays and Thursdays; no injections were given on Wednesdays, Saturdays or Sundays. Different groups of rats were used to test the various drugs (see below); each rat was tested five times with each dose of the drug, the order of doses being counterbalanced across animals according to a Latin square design. Drugs were injected intraperitoneally $\left(2.5 \mathrm{ml} \mathrm{kg}^{-1} ; 25\right.$-gauge needle $) 30$ min before the start of the experimental session. Doses were calculated from the weights of the salts. Cyproheptadine hydrochloride (1 and $\left.5 \mathrm{mg} \mathrm{kg}^{-1} ; n=12\right)$ and chlordiazepoxide hydrochloride ( 3 and $10 \mathrm{mg} \mathrm{kg}^{-1} ; n=12$ ) were dissolved in sterile $0.9 \%$ sodium chloride solution. Clozapine (3.75 and $\left.7.5 \mathrm{mg} \mathrm{kg}^{-1} ; n=15\right)$ and haloperidol (0.05 and $\left.0.1 \mathrm{mg} \mathrm{kg}^{-1} ; n=11\right)$ were dissolved in $0.1 \mathrm{M}$ tartaric acid, buffered to $\mathrm{pH} 5.5$ and diluted with sterile $0.9 \%$ sodium chloride to give the desired concentration. $\Delta^{9}$-tetahydrocannabinol (THC, 1 and $3 \mathrm{mg} \mathrm{kg}^{-1} ; n=12$ ) was dissolved in a mixture of ethanol and Tween $(1: 1)$ and diluted with sterile water to give the desired concentration. Cyproheptadine and THC were obtained from Tocris Bioscience, Bristol, UK; clozapine, haloperidol and chlordiazepoxide were obtained from Sigma Chemical Company, Poole, UK. The doses of clozapine and haloperidol were chosen on the basis of previous findings of the effects of these drugs on progressive-ratio schedule performance (Mobini et al. 2000; Zhang et al. 2005a), the doses of cyproheptadine were chosen on the basis of previous findings with the drug 
discrimination paradigm (Goudie et al. 2007), and the doses of chlordiazepoxide and THC were chosen on the basis of their effects on feeding behaviour (Berridge and Treit 1986; Koch 2001; Williams and Kirkham 2002; Freet et al. 2006).

\section{Data analysis}

The data obtained with each drug were analysed separately. Only the data obtained from the sessions in which injections had been given were used in the analysis.

Peak response rate. The highest overall response rate (see below) attained during performance on the progressive-ratio schedule was compared between treatments by repeated-measures one-way analysis of variance, followed, in the case of a significant effect of treatment, by comparison of each dose of the drug with the vehicle-alone treatment using Dunnett's test.

Highest completed ratio and breakpoint. The breakpoint was defined as the last ratio to be completed before 5 minutes elapsed without any responding. In most cases, this was identical to the highest ratio completed in the session. However, in the case of some rats, the breakpoint criterion was sometimes not met within the 50-minute session. Therefore, both the highest completed ratio and breakpoint were compared between treatment conditions using analyses of variance followed by multiple comparisons with the vehicle-alone condition using Dunnett's test. In the case of the breakpoint, sessions in which the breakpoint criterion was not met were excluded from the analysis.

Overall response rate. Overall response rate was calculated for each ratio by dividing the number of responses by the total time taken to complete the ratio, including the post-reinforcement pause, measured from the end of the preceding reinforcer delivery until the emission of the last response of the ratio (Bizo and 
Killeen 1997). The first ratio (a single response) and any ratios that had not been completed at the end of the session were excluded from the analysis. The raw data were analysed by two-factor analysis of variance (treatment condition $\times$ ratio) with repeated measures on both factors. Equation 1 was fitted to the overall response rate data from each rat under each treatment condition using an iterative least-squares method (SigmaPlot, Version 8.0), and the estimated values of the parameters $\beta, \delta$ and $a$ were derived; goodness of fit was expressed as $r^{2}$, the proportion of the data variance accounted for by the equation. In agreement with previous findings (Mobini et al. 2000; Ho et al. 2003; Zhang et al. 2005a, 2005b; Bezzina et al. 2008a, 2008b; Rickard et al. 2009), examination of the data revealed that in some rats very low response rates were generated under the highest ratios, which did not conform to Equation 1. Therefore the equation was fitted to each rat's data after exclusion of these low rates using the following operational criterion (Mobini et al. 2000). Points were removed successively, starting from the highest ratio completed, when the curvefitting routine generated an abscissa intersection point $(a / \delta)$ which lay to the left of the rightmost empirical datum point; such an intersection implies a negative predicted response rate, which is impossible empirically and specifically precluded by the model (see above, Equation 1). A fit was accepted when the predicted response rates for all the surviving data points had positive values. This procedure seldom eliminated more than one datum point from the data sets derived from individual rats. The estimates of the three parameters of Equation $1(a, \delta$ and $\beta)$ were analysed in the same way as the peak response rate (see above).

Running response rate. Running rate was calculated by dividing the number of responses by the 'run-time' (i.e. the time taken to complete the ratio, excluding the post-reinforcement pause: Bizo et al. 2001). The data were analysed as described 
above. Equation 2 was fitted to the running rate data from the individual rats and the parameter estimates were analysed in the same way as the parameters of Equation 1.

Because the number of ratios completed within a session under a progressiveratio schedule differs among individual subjects, analyses of variance of the raw response rates included only those ratios that were completed by at least $75 \%$ of the rats in each group under each treatment condition (ratios up to and including 62 in the case of the haloperidol series and up to and including 118 in the case of all other drugs), missing values being filled using the value obtained in the highest ratio completed by the subject in question (Rickard et al. 2009). (Note that this limitation did not apply to the quantitative analysis of response rates using Equations 1 and 2, which entailed fitting functions to the data from individual rats.)

A significance criterion of $P<0.05$ was adopted in all statistical analyses.

\section{Results}

Cyproheptadine $(n=12)$

Peak response rate. The mean $( \pm$ SEM) data are shown in Table 1 . There was a significant effect of treatment $[F(2,22)=19.7, P<0.001]$, peak response rate being significantly reduced by the higher dose of cyproheptadine.

Highest completed ratio and breakpoint. The mean $( \pm$ SEM) data are shown in Table 1. There was a significant effect of treatment on the highest completed ratio $[F(2,22)=10.7, P<0.01]$, the ratio being significantly increased by both doses of the drug. The breakpoint was also affected $[F(2,22)=4.0, P<0.05]$, the effect of the higher dose being statistically significant, and there was a dose-related reduction of the proportion of sessions in which the breakpoint criterion was reached $[F(2,22)=$ 18.6, $P<0.001]$. 
Overall response rate. The group mean data under each treatment condition are shown in Fig. 1 (left-hand panel). Response rate tended to be reduced in the case of lower ratios and increased in the case of higher ratios by the higher dose of cyproheptadine. Analysis of variance revealed significant main effects of treatment $[F(2,22)=11.6, P<0.001]$ and ratio $[F(15,165)=16.1, P<0.001]$ and a significant treatment $\times$ ratio interaction $[F(30,330)=2.9, P<0.001]$. The fits of Equation 1 to the group mean data accounted for $>85 \%$ of the total variance (vehicle: $r^{2}=0.98$; cyproheptadine $\left.1 \mathrm{mg} \mathrm{kg}^{-1}: r^{2}=0.95 ; 5 \mathrm{mg} \mathrm{kg}{ }^{-1}: r^{2}=0.86\right)$. The parameters of Equation 1 are shown in Table 2. Cyproheptadine significantly increased the 'specific activation' parameter, $a[F(2,22)=9.1, P<0.001]$ and the 'response time' parameter, $\delta$ $[F(2,22)=12.7, P<0.001]$, the effect of the higher dose being significant in each case. There was no significant effect of cyproheptadine on the 'currency' parameter, $\beta$ $[F(2,22)=1.3, P>0.2]$

Running response rate. The group mean data under each treatment condition are shown in Fig. 1 (right-hand panel). Running rate tended to be reduced in the case of lower ratios by both doses of cyproheptadine. Analysis of variance revealed significant main effects of treatment $[F(2,22)=14.7, P<0.001]$ and ratio $[F(15,165)=$ 81.3, $P<0.001]$ and a significant treatment $\times$ ratio interaction $[F(30,330)=1.5$, $P<0.05]$. The fits of Equation 2 to the group mean data accounted for $>90 \%$ of the total variance (vehicle: $r^{2}=0.97$; cyproheptadine $1 \mathrm{mg} \mathrm{kg}^{-1}: r^{2}=0.98 ; 5 \mathrm{mg} \mathrm{kg}^{-1}: r^{2}=$ 0.96). The parameters of Equation 2 are shown in Table 3. Cyproheptadine significantly reduced the 'initial response rate' parameter, $R_{i}[F(2,22)=5.4, P<0.05]$, the effect of the higher dose being statistically significant. There was no significant effect of cyproheptadine on the 'decay' parameter, $b \quad[F(2,22)=2.4$, NS $]$, or the 'exponent' parameter, $c[F(2,22)=1.8, \mathrm{NS}]$. 
Clozapine $(n=15)$

Peak response rate. There was a significant effect of treatment $[F(2,28)=$ $10.2, P<0.001]$, peak response rate being significantly reduced by the higher dose of clozapine (Table 1).

Highest completed ratio and breakpoint. Clozapine had no significant effect on either measure [highest completed ratio: $F(2,28)=2.6$, NS; breakpoint: $F<1$ ] (Table 1).

Overall response rate. Clozapine tended to reduce overall response rate under the lower ratios and increase it under the higher ratios (Fig. 2, left-hand panel). Analysis of variance revealed significant main effects of treatment $[F(2,28)=10.3$, $P<0.001]$ and ratio $[F(15,210)=7.3, P<0.001]$ and a significant treatment $\times$ ratio interaction $[F(30,420)=3.1, P<0.001]$. Equation 1 accounted for $>85 \%$ of the total variance (vehicle: $r^{2}=0.88$; clozapine $3.75 \mathrm{mg} \mathrm{kg}{ }^{-1}: r^{2}=0.93 ; 7.5 \mathrm{mg} \mathrm{kg}^{-1}: r^{2}=0.92$ ). Analysis of the parameters of Equation 1 (Table 2) showed that $a$ was increased by clozapine $[F(2,28)=10.9, P<0.001]$, the effects of both doses being statistically significant; $\delta$ was increased by clozapine $[F(2,28)=3.4, P<0.05]$, the effect of $7.5 \mathrm{mg}$ $\mathrm{kg}^{-1}$ being statistically significant; $\beta$ was also increased by clozapine $[F(2,28)=3.4$, $P<0.05]$, the effect of $7.5 \mathrm{mg} \mathrm{kg}^{-1}$ being statistically significant.

Running response rate. The group mean data are shown in Fig. 2 (right-hand panel). The higher dose of clozapine reduced response rates in the case of lower ratios. Analysis of variance revealed significant main effects of treatment $[F(2,28)=$ $6.9, P<0.01]$ and ratio $[F(15,210)=74.8, P<0.001]$ and a significant treatment $\times$ ratio interaction $[F(30,420)=1.8, P<0.05]$. Equation 2 accounted for $>90 \%$ of the total variance (vehicle: $r^{2}=0.98$; clozapine $3.75 \mathrm{mg} \mathrm{kg}{ }^{-1}: r^{2}=0.97 ; 7.5 \mathrm{mg} \mathrm{kg}^{-1}: r^{2}=0.97$ ). 
Analysis of the parameters of Equation 2 (Table 3) showed that clozapine significantly reduced $R_{i}[F(2,22)=5.2, P<0.05]$, the effect of the higher dose being statistically significant. There was no significant effect of clozapine on $b[F<1]$ or $c[F<1]$.

Haloperidol $(n=11)$

Peak response rate. There was a significant effect of treatment $[F(2,20)=$ 13.0, $P<0.001]$, peak response rate being significantly reduced by the higher dose of haloperidol (Table 1).

Highest completed ratio and breakpoint. Haloperidol reduced the highest completed ratio $[F(2,20)=23.4, P<0.001]$, the effects of both doses being statistically significant. The breakpoint was also reduced $[F(2,20)=29.8, P<0.001]$, the effect of the both doses being statistically significant, and there was a reduction of the proportion of sessions in which the breakpoint criterion was reached $[F(2,2)=7.7$, $P<0.01]$. (Table 1).

Overall response rate. There was a dose-dependent suppression of overall response rate (Fig. 3, left-hand panel). There were significant main effects of treatment $[F(2,20)=70.5, P<0.001]$ and ratio $[F(11,110)=14.4, P<0.001]$ and a significant treatment $\times$ ratio interaction $[F(22,220)=8.2, P<0.001]$. Equation 1 accounted for $>90 \%$ of the total variance (vehicle: $r^{2}=0.97$; haloperidol $0.05 \mathrm{mg} \mathrm{kg}^{-1}$ : $\left.r^{2}=0.93 ; 0.1 \mathrm{mg} \mathrm{kg}^{-1}: r^{2}=0.92\right)$. Analysis of the parameters of Equation 1 showed that haloperidol significantly reduced the value of $a[F(2,20)=9.2, P<0.001]$ and increased the value of $\delta[F(2,20)=5.2, P<0.05] ; \quad \beta$ was not significantly affected $[F(2,20)=2.9, P>0.05]($ Fig. 3$)$.

Running response rate. The group mean data are shown in Fig. 3 (right-hand panel). There was a dose dependent reduction of response rates. Analysis of variance 
revealed significant main effects of treatment $[F(2,20)=27.4, P<0.001]$ and ratio $[F(11,110)=52.0, P<0.001]$; the interaction term was not significant $[F(22,220)=$ 81.2, NS]. Equation 2 accounted for $>90 \%$ of the total variance (vehicle: $r^{2}=0.98$; haloperidol $\left.0.05 \mathrm{mg} \mathrm{kg}^{-1}: r^{2}=0.99 ; 0.1 \mathrm{mg} \mathrm{kg}^{-1}: r^{2}=0.99\right)$. Analysis of the parameters of Equation 2 (Table 3) showed that haloperidol did not significantly affect $R_{i}$ $[F(2,20)=1.3, \mathrm{NS}]$. There was a significant reduction of $b[F(2,20)=10.4, P<0.01]$ and an increase of $c[F(2,20)=8.2, P<0.01]$ produced by the higher dose.

\section{Chlordiazepoxide $(n=12)$}

Peak response rate. There was a significant effect of treatment $[F(2,22)=6.2$, $P<0.01$ ], peak response rate being significantly increased by the lower dose of chlordiazepoxide only (Table 1).

Highest completed ratio and breakpoint. Chlordiazepoxide increased the highest completed ratio $[F(2,22)=7.7, P<0.001]$, the effects of both doses being statistically significant. The breakpoint was also increased $[F(2,22)=6.3, P<0.01]$, the effect of the lower dose being statistically significant, and there was a concomitant reduction of the proportion of sessions in which the breakpoint criterion was reached $[F(2,2)=5.3, P<0.05] .($ Table 1$)$.

Overall response rate. Chlordiazepoxide tended to increase overall response rates, this being somewhat more apparent in the case of the smaller dose $\left(3 \mathrm{mg} \mathrm{kg}^{-1}\right)$ (Fig. 4, left-hand panel). There were significant main effects of treatment $[F(2,22)=$ 11.6, $P<0.001]$ and ratio $[F(15,165)=22.2, P<0.001]$ and a significant treatment $\times$ ratio interaction $[F(30,330)=1.8, P<0.01]$. Equation 1 accounted for $>90 \%$ of the total variance (vehicle: $r^{2}=0.97$; chlordiazepoxide $3 \mathrm{mg} \mathrm{kg}^{-1}: r^{2}=0.97 ; 10 \mathrm{mg} \mathrm{kg}{ }^{-1}: r^{2}$ $=0.97$ ). Analysis of the parameters of Equation 1 (Table 2) revealed a significant 
effect of treatment on $a[F(2,22)=5.2, P<0.05]$, the increase produced by $10 \mathrm{mg} \mathrm{kg}^{-1}$ being statistically significant. There was also a significant effect on $\delta[F(2,22)=5.2$, $P<0.05]$, reflecting a reduction of this parameter produced by the $3 \mathrm{mg} \mathrm{kg}^{-1}$ dose only. $\beta$ was not significantly affected $[F(2,22)=3.1, P>0.05]$.

Running response rate. The group mean data are shown in Fig. 4 (right-hand panel). The lower dose of chlordiazepoxide produced a modest increase in running response rate. There were significant main effects of treatment $[F(2,22)=10.3$, $P<0.001]$ and ratio $[F(15,165)=66.6, P<0.001]$; the interaction was not significant $[F(30,330)=1.1, \mathrm{NS}]$. Equation 2 accounted for $>90 \%$ of the total variance (vehicle: $r^{2}=0.97$; chlordiazepoxide $\left.3 \mathrm{mg} \mathrm{kg}^{-1}: r^{2}=0.98 ; 10 \mathrm{mg} \mathrm{kg}^{-1}: r^{2}=0.99\right)$. Analysis of the parameters of Equation 2 (Table 3) showed that chlordiazepoxide had no significant effect on $R_{i}[F<1], b[F<1]$ or $c[F(2,22)=1.3, \mathrm{NS}]$.

THC $(n=12)$

Peak response rate. THC had no significant effect on the peak response rate $[F<1]$ (Table 1).

Highest completed ratio and breakpoint. THC had no significant effect on the highest completed ratio $[F(2,22)=1.1, \mathrm{NS}]$ or the breakpoint $[F<1]$. However the higher dose was associated with an increase of the proportion of sessions in which the breakpoint was achieved $[F(2,22)=4.6, P<0.05]$ (Table 1$)$.

Overall response rate. THC had no apparent effect on overall response rate (Fig. 5, left-hand panel). Analysis of variance revealed a significant main effect of ratio $[F(15,165)=15.5, P<0.001]$, but no significant main effect of treatment $[F(2,22)$ $=2.6, \mathrm{NS}]$ and no significant interaction $[F<1]$. Equation 1 accounted for $>90 \%$ of the total variance (vehicle: $r^{2}=0.97$; THC $1 \mathrm{mg} \mathrm{kg}{ }^{-1}: r^{2}=0.97 ; 3 \mathrm{mg} \mathrm{kg}{ }^{-1}: r^{2}=0.97$ ). 
None of the parameters of Equation 1 was significantly affected by the drug $[a$ : $F(2,22)=2.2, P>0.05 ; \delta: F(2,22)=1.6, P>0.1 ; \beta: F<1]$ (Table 3$).$

Running response rate. THC had no significant effect on running response rate (Fig. 5, right-hand panel). There was a significant main effect of ratio $[F(15,165)=$ 93.3, $P<0.001]$, but no significant main effect of treatment $[F<1]$ and no significant interaction $[F(30,330)=1.1, \mathrm{NS}]$. Equation 2 accounted for $>90 \%$ of the total variance (vehicle: $r^{2}=0.98$; THC $1 \mathrm{mg} \mathrm{kg}{ }^{-1}: r^{2}=0.98 ; 3 \mathrm{mg} \mathrm{kg}{ }^{-1}: r^{2}=0.99$ ). None of the parameters of Equation 2 was significantly affected by THC $\left[R_{i}, b, c\right.$ : all $\left.F_{\mathrm{s}}<\right]$. (Table 3).

\section{Discussion}

Performance on the progressive-ratio schedule was similar to that seen in many previous studies (Bizo and Killeen 1997; Mobini et al. 2000; Ho et al. 2003; Kheramin et al. 2005; Zhang et al. 2005a, 2005b; Bezzina et al. 2008a, 2008b; Killeen et al. 2009; Rickard et al. 2009). Overall response rate was bitonically related to ratio size; it increased rapidly to reach a peak, and then declined gradually as the response/reinforcer ratio was progressively increased. The relation between overall response rate and ratio size was well described by Equation 1. In agreement with a recent report (Rickard et al. 2009), running response rate did not conform closely to Equation 1, but was well described by the logistic function defined by Equation 2 .

Previous comparisons of the effects of conventional and atypical antipsychotics on progressive-ratio schedule performance found that the two classes of drugs exerted different patterns of effect on the parameters of Equation 1 (Mobini et al. 2000; Zhang et al. 2005a). Atypical antipsychotics increased the values of both the 'specific activation' parameter, $a$, and the 'response time' parameter, $\delta$; in 
contrast, conventional antipsychotics increased $\delta$, but either reduced or had no effect on $a$. The present results are consistent with these previous findings, in that clozapine increased both $a$ and $\delta$, whereas haloperidol increased $\delta$ and reduced $a$.

The parameter $a$ is believed to provide a quantitative measure of the efficacy or value of reinforcers (Killeen 1994; Bizo and Killeen 1997; Killeen and Sitomer 2003; Reilly 2003; Kheramin et al. 2005; Bezzina et al. 2008a, 2008b; Killeen et al. 2009; Rickard et al. 2009). Thus the opposite effects of clozapine and haloperidol on this parameter are consistent with the notion that clozapine increased and haloperidol reduced the incentive value of the food reinforcer. The decay parameter, $b$, of Equation 2 is also related to incentive value (Rickard et al. 2009). Clozapine tended to increase this parameter, although the effect was not statistically significant, whereas haloperidol significantly reduced it.

The apparent enhancement of the incentive value of food reinforcers by clozapine may be related to this drug's known food intake-enhancing effect (Comer et al. 1997; Hartfield et al. 2003; Goudie et al. 2007). The mechanism underlying this effect is uncertain. Clozapine has a complex receptor binding profile which includes notably high affinities for $5-\mathrm{HT}_{2 \mathrm{~A}}$, histamine $\mathrm{H}_{1}$ and muscarinic $\mathrm{M}_{1}$ receptors (Bymaster 1996); it has been suggested that the combined blockade of all these receptors is responsible for the hyperphagic effects of this drug (Hartfield et al. 2003).

A reduction of the incentive value of food reinforcers by haloperidol is consistent with the well known 'anhedonia theory' which posits that conventional antipsychotics reduce the rewarding value of food and other reinforcers by blocking dopamine $\mathrm{D}_{2}$ receptors in limbic structures (Wise 1982, 2006). Evidence consistent with an antihedonic effect of conventional antipsychotics derives from a wide variety of behavioural approaches, including operant response rate measures (Heyman 1983; 
Morley et al. 1984; Salamone 1987), conditioned reinforcement paradigms (Cador et al. 1991), and the rate of extinction of operant responses (Wise et al. 1978; Salamone 1986). In some cases, these observations may be susceptible to an alternative interpretation in terms of a motor debilitating effect of the drugs (see Salamone et al. 1994, 1997). Quantitative analysis of schedule-controlled behaviour based on Killeen's (1994) MPR model enables these two processes to be separated mathematically. Previous applications of this method indicated a predominant effect of haloperidol on motor capacity (Mobini et al. 2000; Zhang et al. 2005a). However, the present results indicate that haloperidol also produced a substantial reduction of the incentive value of the food reinforcer.

Since $\delta$ is believed to be inversely related to the motor capacity of the organism (Killeen 1994; Bizo and Killeen 1997; Killeen and Sitomer 2003; Reilly 2003; Kheramin et al. 2005; Bezzina et al. 2008a, 2008b; Killeen et al. 2009; Rickard et al. 2009), the increase in this parameter produced by both clozapine and haloperidol is consistent with an adverse effect of both drugs on motor functioning. The parameter $R_{i}$ of Equation 2 may also be related to motor functioning, since it expresses the maximum rate of emission of trains of operant responses; however, unlike $\delta$, it is not influenced by the post-reinforcement pause, which may in part reflect post-prandial effects of the reinforcer (Rickard et al. 2009). Both clozapine and haloperidol tended to reduce this parameter, the effect being statistically significant only in the case of clozapine.

The apparent motor debilitating effects of clozapine and haloperidol are unlikely to reflect the same underlying process. In clozapine's case the effect may be related to sedation, a known side-effect of this drug which is generally attributed to the blockade of central $\mathrm{H}_{1}$ receptors (King and Waddington 2004). Haloperidol's 
effect on the motor parameters of Equations 1 and 2 is more likely to reflect blockade of $\mathrm{D}_{2}$ receptors in the basal ganglia, the basis of the ubiquitous extrapyramidal motor side-effects of conventional antipsychotics (Cunningham Owens 1999).

Both clozapine and haloperidol produced modest increases in the value of the currency parameter, $\beta$, although this effect only reached statistical significance in the case of clozapine. The interpretation of this finding is unclear. Increases in this parameter have been found to occur following increases in reinforcer size (Bizo et al. 2001; Bezzina et al. 2008a; Rickard et al. 2009), possibly reflecting the propensity of larger reinforcers to induce more effective response-reinforcer coupling (Killeen 1994; Bizo et al. 2001; Rickard et al. 2009). This might suggest that clozapine increased the efficiency of response-reinforcer coupling in this experiment. However, we are reluctant to attribute theoretical significance to the present finding, because previous experiments have not generally found reliable effects of clozapine and other antipsychotics on this parameter (Mobini et al. 2000; Zhang et al. 2005a, 2005b).

The main purpose of this experiment was to compare the effects of cyproheptadine and clozapine on progressive-ratio schedule performance. The results indicate that the two drugs had similar profiles of effect on the parameters of Equations 1 and 2. On the basis of the theoretical interpretation of these parameters discussed above, the present results are thus consistent with the notion that cyproheptadine, like clozapine, increased the incentive value of the food reinforcer and induced a degree of motor debilitation. An increase in the incentive value of food reinforcers by cyproheptadine may be related to the known food intake-enhancing effect of this drug, an effect that it shares with clozapine (Hartfield et al. 2003; Goudie et al. 2007). It has been proposed that the hyperphagic effects of both drugs reflect the combined blockade of central 5- $\mathrm{HT}_{2} \mathrm{~A}, \mathrm{H}_{1}$ and $\mathrm{M}_{1}$ receptors (Hartfield et al. 2003; 
Goudie et al. 2007). The apparent motor debilitating effects of both drugs (increase in $\delta$ and reduction of $R_{i}$ ) may reflect sedation which may be attributable to $\mathrm{H}_{1}$ receptor blockade in both cases.

The similar pharmacological profiles of cyproheptadine and clozapine have led to the suggestion that cyproheptadine may be of value in the management of schizophrenia when given in conjunction with a conventional antipsychotic, particularly in the case of patients for whom negative symptoms are especially troublesome. Although attempts to verify this proposal in clinical studies have so far yielded mixed results (see Introduction), the finding that cyproheptadine, like clozapine, may enhance incentive reinforcer value suggests that further clinical studies in studies in which cyproheptadine supplements a conventional antipsychotic may be worthwhile (see Goudie et al. 2007). It must be emphasized, however, that the present results were obtained exclusively with food reinforcers, and it remains to be established whether cyproheptadine's and clozapine's effects reflect interactions with general reward processes, rather than with mechanisms specific to food reinforcement. Further experimental work is needed in order to address this matter.

Combined treatment with cyproheptadine and haloperidol was not tested in these experiments. It would be of interest, in future experiments, to examine the effect of this treatment combination on different behavioural paradigms, in view of the suggestion that combined treatment with cyproheptadine and a conventional antipsychotic may confer some advantages in the management of schizophrenia (see above). However, it is questionable whether the progressive-ratio schedule would be the ideal model for assessing the utility of this treatment. The putative clinical value of this treatment approach resides in the combination of a drug that may alleviate anhedonia and other negative symptoms (i.e cyproheptadine) and a drug with known 
ability to suppress positive symptoms (i.e. haloperidol). The quantitative analysis of progressive-ratio schedule performance adopted here provides a means of assessing the incentive value of positive reinforcers, and may therefore provide a useful measure of the propensity of drugs to alleviate negative symptoms; however it offers no insights into ability of drugs to suppress positive psychotic symptoms.

Chlordiazepoxide's effect on the parameters of Equations 1 and 2 is consistent with an increase in the incentive value of the reinforcer (increases in $a$ and $b$ ). However, unlike clozapine and cyproheptadine, its effect is not suggestive of motor impairment; indeed the lower dose actually reduced $\delta$ and increased $R_{i}$, suggesting a modest facilitation of operant responding. The increase in reinforcer value may be related to chlordiazepoxide's known ability to facilitate feeding in rodents (Berridge and Treit, 1986; Freet et al. 2006). The mechanism underlying benzodiazepines' appetite-enhancing effect is uncertain. However, since the main pharmacological action of these drugs is to facilitate $\gamma$-aminobutyric acid (GABA)-mediated functions, and they do not interact directly with $5-\mathrm{HT}_{2 \mathrm{~A}}$ or $\mathrm{H}_{1}$ receptors (Cooper 2004), the mechanism proposed to account for clozapine's and cyproheptadine's effects on food intake and incentive value is unlikely to be responsible for chlordiazepoxide's effects.

THC had no significant effect on performance on the progressive-ratio schedule. This negative result was unexpected in view of THC's known appetitestimulating effect (Abel 1975; Williams et al. 1998; Williams and Kirkham 1999) and previous reports of its ability to increase the breakpoint in progressive-ratio schedules (Higgs et al. 2005). It is possible that the doses used in this experiment were inadequate to alter the incentive value of the food reinforcer. However, these doses were selected on the basis of previous studies that reported increases in food intake (Higgs et al. 2005; Jarrett et al. 2005). The effect of cannabinoids on food 
reinforcement is known to differ between different foodstuffs, being especially pronounced in the case of sweet foods (Ward and Dykstra 2005). The reinforcer pellets used in these experiments are more palatable than standard laboratory chow, but have no sucrose or other carbohydrate content (TestDiet published data). It may be of interest in future experiments to compare the effects of THC on the parameters of Equation 1 using progressive-ratio schedules employing carbohydrohydrate reinforcers.

The present findings provide a further illustration of the implications of Killeen's (1994) MPR model for interpretating the effects of neuropharmacological interventions on progressive-ratio schedule performance (for review, see Killeen et al. 2009; Rickard et al. 2009). According to MPR, the traditional index of performance on this schedule (the breakpoint) is a hybrid measure, being jointly determined by the incentive value of the reinforcer, represented by $a$, and the motor limitations of the organism, represented by $\delta$. The estimated value of the breakpoint, derived by extrapolation of the descending limb of the response rate function, is defined as $a / \delta$. In the case of interventions that have little impact on motor performance, changes in the breakpoint may provide a reliable indication of changes of incentive value. However, an effect on motor performance may augment, attenuate or even completely override the impact of a change of incentive value on the breakpoint. In the present experiments, there was a general tendency for changes in $a$ to coincide with changes in the breakpoint. For example both doses of cyproheptadine and the lower dose of chlordiazepoxide increased $a$ and the breakpoint, whereas haloperidol produced dosedependent reductions of both these measures. Clozapine, however, did not significantly alter the breakpoint, evidently because the effects of the drug on $a$ and $\delta$ exerted opposing influences on the breakpoint. 
The breakpoint also presents practical difficulties for the behavioural pharmacologist. It is usual to describe the breakpoint as the response/reinforcer ratio at which responding ceases. However, the operational definition of the cessation of responding is arbitrary, and different criteria have been adopted by different workers (see Killeen et al. 2009). Moreover, allowing the experimental session to become extended for an indefinite period until the breakpoint is reached can result in test periods that differ in length between subjects and conditions, clearly a complicating factor when the effects of acute drug treatments are compared. In the present experiments, as in many previous studies (e.g. Aberman et al. 1998; Zhang et al. 2005a, 2005b), time-constrained sessions were used. Although this avoids the problem of variable session length, it results in the formal breakpoint criterion (in the present case, 5 minutes without responding) not being attained by all subjects in all sessions, and necessitates either the elimination of data from sessions in which the criterion was not reached or the use of some other measure, such as the highest ratio completed within the time-constrained session. As shown in Table 1, there was a general tendency for increases in the highest completed ratio and the breakpoint to be associated with a reduction of the percentage of sessions in which the breakpoint criterion was reached. As argued elsewhere (Killeen et al. 2009; Rickard et al. 2009), the mathematical approach exemplified by MPR, by deriving parameter estimates for individual subjects, avoids many of the practical, as well as the theoretical difficulties associated with the use of the breakpoint.

The theoretical basis of the mathematical analysis employed in these experiments deserves some comment. Killeen's (1994) model, from which Equation 1 is derived, is based on a coherent set of principles that are proposed to determine characteristic patterns of responding generated by different schedules of 
reinforcement. These principles include the activation of behaviour by reinforcers (reflected in $a$ ), biological constraints on response rate (reflected in $\delta$ ), and the coupling of operant responses to reinforcers (reflected in $\beta$ ). As reviewed above, Equation 1 has been found to provide a satisfactory account of overall response rate in progressive-ratio schedules in a number of previous studies. However, its failure to provide an adequate description of running response rate in these schedules prompted Rickard et al. (2009) to propose Equation 2 as an empirical descriptor of running rate. Although the present data confirm the utility of both equations to describe the effects of drugs on schedule-controlled behaviour, it must be acknowledged that the use of separate models to describe the overall and running response rates, one theoretically based and the other essentially descriptive, is less than satisfactactory. An integrated mathematical account of the two performance measures will be an important goal of the future development of Killeen's MPR model (Killeen 1994; Killeen et al. 1999).

In summary, the present results confirm the differing effects of haloperidol and clozapine on progressive-ratio schedule performance, and provide further indication that cyproheptadine's behavioural effects in rats resemble those of clozapine. Quantitative analysis based on Killeen's (1994) theoretical model of schedule-controlled behaviour, MPR, indicated that both clozapine and cyproheptadine enhanced the incentive value of the food reinforcer and induced some degree of motor impairment. The results further confirm the utility of quantitative analysis of progressive-ratio schedule performance based on MPR for investigations of the effects of drugs on motivational processes (Killeen et al. 2009; Rickard et al. 2009).

Acknowledgements. This work was supported by the Universities of Liverpool and 
Nottingham. CMOS was supported by an MRC/DTA PhD studentship. LVT was supported by a PhD studentship awarded by the National Science Council of Mexico (CONACYT). We are grateful to Ms V.K. Bak for skilled technical help. 


\section{References}

Abel EL (1975) Cannabis: effects on hunger and thirst. Behav Biol 15:255-281

Aberman JE, Ward SJ, Salamone JD (1998) Effects of dopamine antagonists and accumbens dopamine depletions on time-constrained progressive-ratio performance. Pharmacol Biochem Behav 61:341-348

Akhhondzadeh S, Mohammedi M, Amini-Nooshabadi H, Davari-Ashtiani R (1999) Cyproheptadine in treatment of chronic schizophrenia: a double-blind placebocontrolled study. J Clin Pharm Ther 24:49-52

Arnold J, Roberts DCS (1997) A critique of fixed and progressive ratio schedules used to examine the neural substrates of drug reinforcement. Pharmacol Biochem Behav 57:441-447

Barr AM, Philips AG (1998) Withdrawal following repeated exposure to d-amphetamine decreases responding for a sucrose solution as measured by a progressive ratio schedule of reinforcement. Psychopharmacology 141:99-106

Bacher NM, Sabzone MM, Kauo B (1994) Cyproheptadine in treatment resistant chronic schizophrenics with prior negative response to fluoxetine. J Clin Psychopharmac 14:424-425

Berridge KC, Treit D (1986) Chlordiazepoxide directly enhances positive ingestive reactions in rats. Pharmacol Biochem Behav 24:217-221

Bezzina G, Body S, Cheung THC, Hampson CL, Deakin JFW, Anderson IM, Szabadi E, Bradshaw CM (2008a) Effect of quinolinic acid-induced lesions of the nucleus accumbens core on performance on a progressive ratio schedule of reinforcement: implications for inter-temporal choice. Psychopharmacology 197: 339-350.

Bezzina G, den Boon FS, Hampson CL, Cheung THC, Body S, Bradshaw CM, 
Szabadi E, Anderson IM, Deakin JFW (2008b) Effect of quinolinic acidinduced lesions of the subthalamic nucleus on performance on a progressiveratio schedule of reinforcement: a quantitative analysis. Behav Brain Res 195: $223-230$

Bizo LA, Killeen PR (1997) Models of ratio schedule performance. J Exp Psychol: Anim Behav Proc 23:351-367

Bizo LA, Kettle LC, Killeen PR (2001) Rats don't always respond faster for more food. Anim Learn Behav 29: 66-78

Bymaster F, Calligaro D, Falcone J, Marsh R, Moore N, Tye N, Seeman P, Wong D (1996) Radioreceptor binding profile of the atypical antipsychotic olanzapine. Neuropsychopharmacol 14:87-96

Cador M, Taylor JR, Robbins TW (1991) Potentiation of the effects of reward-related stimuli by dopaminergic-dependent mechanisms in the nucleus accumbens. Psychopharmacology 104:377-385

Chaudhry I, Soni S, Hellewell J, Deakin JFW (2002) Effects of the 5-HT antagonist cyproheptadine on neuropsychological function in chronic schizophrenia. Schizophrenia Res 53:17-24

Cheeta S, Brooks S, Willner P (1995) Effects of reinforcer sweetness and the D2/D3 antagonist raclopride on progressive ratio operant responding. Behav Pharmacol 6:127-132

Cilia J, Piper DC, Upton N, Hagan JJ (2001) Clozapine enhances breakpoint in common marmosets responding on a progressive ratio schedule. Psychopharmacology 155:135-143

Comer S, Haney M, Fischman M, Foltin R (1997) Cyproheptadine produced modest increases in total caloric intake by humans. Physiol Behav 62:831-839 
Cooper SJ (2004) Anxiolytics, sedatives and hypnotics. In: King DJ (ed), Seminars in Psychopharmacology, second edition. London, Gaskell, pp 141-177

Corrigan PW, Reinke RR, Landsberger SA, Charate A, Toombs GA (2003) The effects of atypical antipsychotic medications on psychosocial outcomes. Schizophrenia Res 63:97-101

Cunningham Owens DG (1999) A guide to the extrapyramidal side-effects of antipsychotic drugs. Cambridge, Cambridge University Press

Freet CS, Tesche JD, Tompers DM, Riegel KE, Grigson PS (2006) Lewis rats are more sensitive than Fischer rats to successive negative contrast, but less sensitive to the anxiolytic and appetite-stimulating effects of chlordiazepoxide. Pharmacol Biochem Behav 85:378-384

Goudie AJ, Cooper GD, Cole JC, Sumnall HR (2007) Cyproheptadine resembels clozapine in vivo folowing both acute and chronic administration in rats. J Psychopharmac 21:179-190

Hamill S, Trevitt JT, Nowend KL, Carlson BB, Salamone JD (1999) Nucleus accumbens dopamine depletion and time-contsrained progressive ratio performance: effects of different ratio requirements. Pharmacol Biochem Behav 64:21-27

Hartfield A, Moore N, Clifton P (2003) Serotonergic and histaminergic mechanisms involved in intralipid drinking? Pharmacol Biochem Behav 76:251-258

Heyman GM (1983) A parametric evaluation of the hedonic and motoric effects of drugs: pimozide and amphetamine. J Exp Anal Behav 40:113-122

Higgs S, Barber DJ, Cooper AJ, Terry P (2005) Differential effects of two cannabinoid receptor antagonists on progressive ratio responding for food and free-feeding in rats. Behav Pharmac 16:389-393 
Ho M-Y, Body S, Kheramin S, Bradshaw CM, Szabadi E (2003) Effects of 8-OHDPAT and WAY-100635 on performance on a time-constrained progressiveratio schedule. Psychopharmacology 167:137-144

Hodos W (1961) Progressive ratio as a measure of reward strength. Science 134: 943-944

Hodos W, Kalman G (1963) Effects of increment size and reinforcer volume on progressive ratio performance. J Exp Anal Behav 6:389-392

Ichikawa J, Ishii H, Bonaccorsco S, Fowler WL, O’Laughlin IA, Meltzer HY (2001) $5-\mathrm{HT}_{2 \mathrm{~A}}$ and $\mathrm{D}_{2}$ receptor blockade increases cortical DA release via $5-\mathrm{HT}_{1 \mathrm{~A}}$ receptor activation: a possible mechanism of atypical antipsychotic-induced cortical dopamine release. J Neurochem 76:1521-1531

Jarrett MM, Limebeer CL, Parker LA (2005) Effect of $\Delta^{9}$-tetrahydrocannabinol on sucrose palatability as measured by the taste reactivity test. Physiol Behav $86: 475-479$

Kapur S, Zipursky R, Jones C, Remington G, Houle S (2000) Relationship between dopamine $\mathrm{D}_{2}$ occupancy, clinical response, and side-effects: a double-blind PET study of first-episode schizophrenia. Am J Psychiat 157: 514-520

Ketelaars C, Bruinvels J (1989) The anti-conflict effect of cyproheptadine is not mediated by its 5-hydroxytryptamine antagonistic property. Life Sci 44:17431749

Kheramin S, Body S, Miranda Herrera F, Bradshaw CM, Szabadi E, Deakin JFW, Anderson IM (2005) The effect of orbital prefrontal cortex lesions on performance on a progressive ratio schedule: implications for models of intertemporal choice. Behav Brain Res 156:145-152

Killeeen PR (1994) Mathematical principles of reinforcement. Behav Brain Sci 
$17: 105-172$

Killeen PR, Sitomer MT (2003) MPR. Behav Proc 62:49-64

Killeen PR, Posadas-Sanchez D, Johansen EB, Thrailkill EA (2009) Progressive ratio schedules of reinforcement. J Exp Psychol: Anim Behav Proc 35: 35-50

King DJ, Waddington JL (2004) Antipsychotic drugs and the treatment of schizophrenia. In: King DJ (ed), Seminars in Psychopharmacology, second edition. London, Gaskell, pp 316-380

Kirkham TC, Williams (2001) Synergistic effects of opioid and cannabinoid antagonists on food intake. Psychopharmacology 153:267-270

Koch JE (2001) $\Delta^{9}$-THC stimulates food intake in Lewis rats: Effects on chow, high fat and sweet high-fat diets. Pharmacol Biochem Behav 68:539-543

Lee H, Song D, Kim J, Lee Y, Han E, Yoo K (1995) Cyproheptadine augmentation of haloperidol in chronic schizophrenic patients: a double-blind placebocontrolled study. Int Clin Psychopharmac 10:67-72

Meltzer H, Matsubara S, Lee J-C (1989) Classification of typical and atypical antipsychotic drugs on the basis of dopamine D-1, D-2 and serotonin-2 pKi values. J Pharmac Exp Ther 251:238-246

Meltzer H, Perry E, Jayathilake K (2003) Clozapine-induced weight gain predicts improvement in psychopathology. Schizophrenia Res 59:19-27

Mobini S, Chiang T-J, Ho M-Y, Bradshaw CM, Szabadi E (2000) Comparison of the effects of clozapine, haloperidol, chlorpromazine and d-amphetamine on performance on a time-constrained progressive ratio schedule and on locomotor behaviour in the rat. Psychopharmacology 152:47-54

Moore N, Tye N, Axton M, Risius F (1992) The behavioral pharmacology of olanzapine, a novel 'atypical' antipsychotic agent. J Pharmacol Exp Ther 
262:545-551

Morley MJ, Bradshaw CM, Szabadi E (1984) The effects of pimozide on variableinterval performance: a test of the 'anhedonia' hypothesis of the mode of action of neuroleptic drugs. Psychopharmacology 84:531-536

Müller-Spahn F (2002) Current use of atypical antipsychotics. Eur Psychiat 17 suppl $4: 377-384$

Reilly MP (2003) Extending mathematical principles of reinforcement into the domain of behavioral pharmacology. Behav Proc 62:75-88

Rickard JF, Body S, Zhang Z, Bradshaw CM, Szabadi E (2009) Effect of reinforcer magnitude on performance maintained by progressive-ratio schedules. J Exp Anal Behav 91: 75-87

Roberts DCS, Richardson NR (1992) Self-administration of psychostimulants using progressive ratio schedules of reinforcement. In: Boulton A, Baker G, Wu PH (eds) Neuromethods., vol 24: animal models of drug addiction. New York, Humana, pp 233-269

Rowlett JK (2000) A labor-supply analysis of cocaine self-administration under progressive ratio schedules: antecedents, methodologies, and perspectives. Psychopharmacology 153:1-16

Salamone JD (1986) Different effects of haloperidol and extinction on instrumental behaviors. Psychopharmacology 88:18-23

Salamone JD (1987) The actions of neuroleptic drugs on appetitive instrumental behaviors. In: Iversen LL, Iversen SD, Snyder SH (eds) Handbook of psychopharmacology. Plenum, New York, pp 575-608

Salamone JD, Cousins MS, Butcher S (1994) Anhedonia or anergia? Effects of haloperidol and nucleus accumbens dopamine depletion on instrumental 
response selection in a T-maze cost/benefit procedure. Behav Brain Res $65: 221-229$

Salamone JD, Cousins MS, Snyder BJ (1997) Behavioral functions of nucleus accumbens dopamine: Empirical and conceptual problems with the anhedonia hypothesis. Neurosci biobehav Rev 21:341-359

Schmidt AW, Lebel LA, Howard HR, Zorn SH (2001) Ziprasidone: a novel antipsychotic agent with a unique human receptor binding profile. Eur J Pharmac 425:197-201

Seeman P, Lee T, Chau WM, Wong K (1976) Antipsychotic drug dose and neuroleptic/dopamine receptors. Nature 261:717-719

Silver H, Blacker M, Weller M, Lerer B (1989) Treatment of chronic schizophrenia with cyproheptadine. Biol Psychiat 25:502-504

Silver H, Blacker M, Weller M, Lerer B (1991) Treatment of chronic schizophrenia with cyproheptadine: a double-blind placebo-controlled study. Biol Psychiat $30: 523-525$

Skjoldager P, Pierre PJ, Mittleman G (1993) Reinforcer magnitude and progressive ratio responding in the rat: effects of increased effort, prefeeding, and extinction. Learn Motiv 24:303-343

Stafford D, Branch MN (1998) Effects of step size and break-point criterion on progressive-ratio performance. J Exp Anal Behav 70: 123-138

Stafford D, LeSage MG, Glowa JR (1998) Progressive-ratio schedules of drug delivery in the analysis of drug self-administration: a review.

Psychopharmacology 139:169-184

Test Diet. Technical data sheet on grain-based rodent tablet 5TUM. www.testdiet.com Ward SJ, Dykstra LA (2005) The role of $\mathrm{CB}_{1}$ receptors in sweet versus fat 
reinforcement: Effect of $\mathrm{CB}_{1}$ receptor depletion, $\mathrm{CB}_{1}$ receptor antagonism (SR141716A) and $\mathrm{CB}_{1}$ receptor agonism (CP-55940). Behav Pharmac 16:381388

Williams CM, Kirkham TC (2002) Observational analysis of feeding induced by $\Delta^{9}$ THC and anandamide. Physiol Behav 76:241-250

Williams CM, Rogers PJ, Kirkham TC (1998) Hyperphagia in pre-fed rats following oral $\Delta^{9}$-THC. Physiol Behav 65:343-346

Wise RA (1982) Neuroleptics and operant behavior: the anhedonia hypothesis. Brain Behav Sci 5:39-87

Wise RA (2006) Role of brain dopamine in food reward and reinforcement. Phil Trans Roy Soc Lond B: Biol Sci 361:1149-1158

Wise RA, Rompre P-P (1989) Brain dopamine and reward. Ann Rev Psychol 40:191225

Wise RA, Spindler J, de Wit H, Gerber GJ (1978) Neuroleptic-induced 'anhedonia' in rats: pimozide blcks the reward quality of food. Science 201:262-264

Young R, Khorana N, Bondareva T, Glennon R (2005) Pizotyline effectively attenuates the stimulus effects of N-methyl-3,4-methylenedioxyamphetamine (MDMA). Pharmacol Biochem Behav 82:404-410

Zhang, Z, Rickard JF, Asgari K, Body S, Bradshaw CM, Szabadi E (2005a) Quantitative analysis of the effects of some "atypical" and "conventional" antipsychotics on progressive ratio schedule performance. Psychopharmacology $179: 489-497$

Zhang Z, Rickard JF, Asgari K, Body S, Bradshaw CM, Szabadi E (2005b) Comparison of the effects of clozapine and 8-hydroxy-2-(di- $n$ propylamino)tetralin (8-OH-DPAT) on progressive ratio schedule performance: 
Evidence against the involvement of 5- $\mathrm{HT}_{1 \mathrm{~A}}$ receptors in the behavioural effects of clozapine. Psychopharmacology 181:381-391 
Table 1. Peak response rate, breakpoint and highest completed ratio under each treatment condition (mean $\pm \mathrm{SEM})$

\begin{tabular}{|c|c|c|c|c|}
\hline Treatment & $\begin{array}{l}\text { Peak response rate } \\
\left(\text { responses } \min ^{-1} \text { ) }\right.\end{array}$ & $\begin{array}{c}\text { Breakpoint } \\
\text { (ratio) }\end{array}$ & $\begin{array}{c}\text { Percent } \\
\text { breakpoint }^{\mathrm{a}}\end{array}$ & $\begin{array}{c}\text { Highest } \\
\text { completed ratio }\end{array}$ \\
\hline \multicolumn{5}{|c|}{ Cyproheptadine } \\
\hline vehicle & $129.1 \pm 5.2$ & $116.8 \pm 13.8$ & $82.9 \pm 7.5$ & $135.7 \pm 16.9$ \\
\hline $1 \mathrm{mg} \mathrm{kg}^{-1}$ & $132.0 \pm 6.1$ & $140.6 \pm 16.0$ & $62.5 \pm 10.5 *$ & $186.3 \pm 20.5^{*}$ \\
\hline $5 \mathrm{mg} \mathrm{kg}^{-1}$ & $102.1 \pm 6.6^{*}$ & $189.0 \pm 33.3^{*}$ & $26.4 \pm 9.3^{*}$ & $226.5 \pm 29.3^{*}$ \\
\hline \multicolumn{5}{|l|}{ Clozapine } \\
\hline vehicle & $92.4 \pm 6.7$ & $125.9 \pm 10.7$ & $91.7 \pm 5.8$ & $134.5 \pm 10.6$ \\
\hline $3.75 \mathrm{mg} \mathrm{kg}^{-1}$ & $82.6 \pm 7.7$ & $135.5 \pm 16.4$ & $88.1 \pm 7.5$ & $163.6 \pm 19.8$ \\
\hline $7.5 \mathrm{mg} \mathrm{kg}^{-1}$ & $70.4 \pm 5.5^{*}$ & $137.7 \pm 16.8$ & $79.8 \pm 8.6$ & $159.8 \pm 18.1$ \\
\hline \multicolumn{5}{|l|}{ Haloperidol } \\
\hline vehicle & $108.1 \pm 9.5$ & $126.8 \pm 18.9$ & $82.5 \pm 10.1$ & $208.0 \pm 39.6$ \\
\hline $0.05 \mathrm{mg} \mathrm{kg}^{-1}$ & $97.7 \pm 7.1$ & $59.8 \pm 7.4^{*}$ & $77.3 \pm 9.8$ & $112.2 \pm 27.0^{*}$ \\
\hline $0.1 \mathrm{mg} \mathrm{kg}^{-1}$ & $78.8 \pm 7.4^{*}$ & $20.1 \pm 2.5^{*}$ & $100.0 \pm 0.0^{*}$ & $28.7 \pm 5.9^{*}$ \\
\hline \multicolumn{5}{|c|}{ Chlordiazepoxide } \\
\hline vehicle & $126.0 \pm 6.1$ & $105.2 \pm 13.5$ & $88.5 \pm 6.4$ & $120.4 \pm 16.2$ \\
\hline $3 \mathrm{mg} \mathrm{kg}^{-1}$ & $145.4 \pm 8.7 *$ & $151.4 \pm 18.8^{*}$ & $63.3 \pm 10.1 *$ & $178.7 \pm 20.8^{*}$ \\
\hline $10 \mathrm{mg} \mathrm{kg}^{-1}$ & $127.5 \pm 9.6$ & $116.9 \pm 15.3$ & $80.0 \pm 4.9$ & $161.3 \pm 21.7^{*}$ \\
\hline \multicolumn{5}{|l|}{$T H C$} \\
\hline vehicle & $134.5 \pm 7.8$ & $105.8 \pm 14.3$ & $92.7 \pm 5.0$ & $127.4 \pm 18.2$ \\
\hline $1 \mathrm{mg} \mathrm{kg}^{-1}$ & $131.4 \pm 7.4$ & $112.5 \pm 15.5$ & $85.8 \pm 7.8$ & $134.0 \pm 19.9$ \\
\hline $3 \mathrm{mg} \mathrm{kg}^{-1}$ & $133.6 \pm 7.0$ & $108.9 \pm 13.1$ & $81.3 \pm 7.9^{*}$ & $127.4 \pm 17.5$ \\
\hline
\end{tabular}

${ }^{\text {a }}$ Percentage of sessions in which the breakpoint criterion was reached (see text)

* Significance of difference from vehicle control, $P<0.05$ (see text for details) 
Table 2. Parameters of Equation 1 (group mean data \pm SEM)

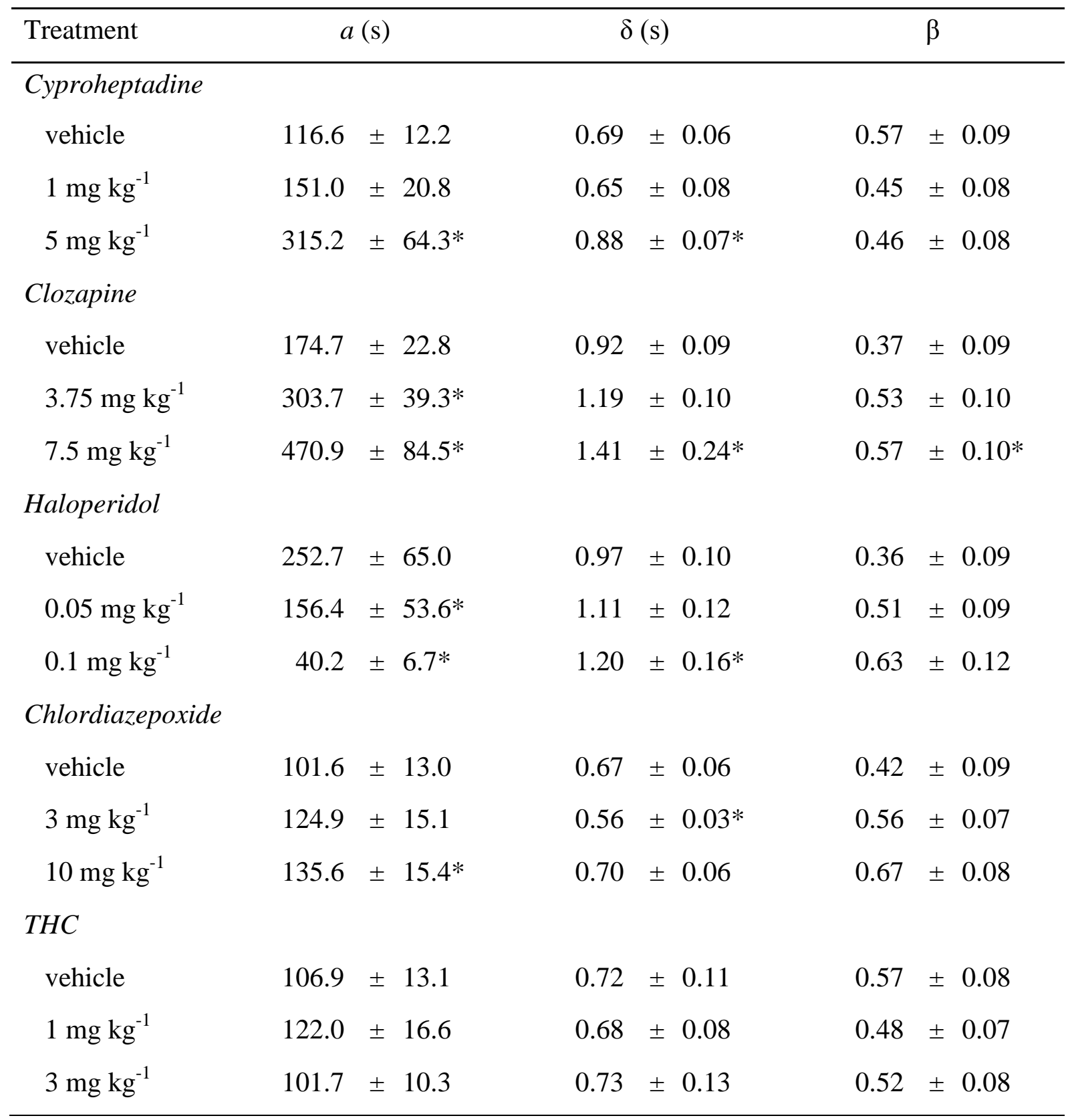

* Significance of difference from vehicle control, $P<0.05$ (see text for details) 
Table 3. Parameters of Equation 2 (group mean data \pm SEM)

\begin{tabular}{|c|c|c|c|c|c|}
\hline Treatment & $R_{i}\left(\right.$ responses $\left.\min ^{-1}\right)$ & & $b$ & & $c$ \\
\hline \multicolumn{6}{|c|}{ Cyproheptadine } \\
\hline vehicle & $222.0 \pm 19.1$ & 30.0 & \pm 13.1 & 1.43 & \pm 0.20 \\
\hline $1 \mathrm{mg} \mathrm{kg}^{-1}$ & $191.7 \pm 15.9$ & 66.9 & \pm 12.9 & 1.40 & \pm 0.11 \\
\hline $5 \mathrm{mg} \mathrm{kg}^{-1}$ & $151.9 \pm 19.2^{*}$ & 85.0 & \pm 27.0 & 2.47 & \pm 0.84 \\
\hline \multicolumn{6}{|l|}{ Clozapine } \\
\hline vehicle & $154.5 \pm 10.8$ & 59.4 & \pm 8.8 & 1.61 & \pm 0.21 \\
\hline $3.75 \mathrm{mg} \mathrm{kg}^{-1}$ & $138.7 \pm 14.1$ & 66.5 & \pm 12.3 & 1.40 & \pm 0.16 \\
\hline $7.5 \mathrm{mg} \mathrm{kg}^{-1}$ & $107.3 \pm 11.4 *$ & 72.3 & \pm 14.4 & 2.21 & \pm 0.72 \\
\hline \multicolumn{6}{|l|}{ Haloperidol } \\
\hline vehicle & $158.1 \pm 15.9$ & 59.5 & \pm 9.6 & 1.31 & \pm 0.12 \\
\hline $0.05 \mathrm{mg} \mathrm{kg}^{-1}$ & $148.1 \pm 13.1$ & 37.3 & \pm 9.4 & 1.78 & \pm 0.20 \\
\hline $0.1 \mathrm{mg} \mathrm{kg}^{-1}$ & $133.4 \pm 17.4$ & 14.5 & $\pm 2.3^{*}$ & 3.88 & $\pm 0.75^{*}$ \\
\hline \multicolumn{6}{|c|}{ Chlordiazepoxide } \\
\hline vehicle & $208.1 \pm 20.2$ & 51.6 & \pm 13.7 & 1.84 & \pm 0.40 \\
\hline $3 \mathrm{mg} \mathrm{kg}^{-1}$ & $210.7 \pm 17.7$ & 57.7 & \pm 10.8 & 1.44 & \pm 0.21 \\
\hline $10 \mathrm{mg} \mathrm{kg}^{-1}$ & $186.5 \pm 15.0$ & 53.4 & \pm 12.4 & 1.36 & \pm 0.15 \\
\hline \multicolumn{6}{|l|}{$T H C$} \\
\hline vehicle & $207.2 \pm 20.1$ & 48.2 & \pm 7.9 & 1.73 & \pm 0.19 \\
\hline $1 \mathrm{mg} \mathrm{kg}^{-1}$ & $201.8 \pm 16.0$ & 53.8 & \pm 11.4 & 1.82 & \pm 0.23 \\
\hline $3 \mathrm{mg} \mathrm{kg}^{-1}$ & $189.5 \pm 9.5$ & 57.0 & \pm 9.7 & 1.87 & \pm 0.11 \\
\hline
\end{tabular}

* Significance of difference from vehicle control, $P<0.05$ (see text for details) 
Figure 1. Effects of cyproheptadine (CYPRO) on progressive-ratio schedule performance. Left-hand graph: relation between overall response rate and the response/reinforcer ratio, $N$. Unfilled circles: vehicle-alone treatment; upright filled triangles: cyproheptadine $1 \mathrm{mg} \mathrm{kg}{ }^{-1}$; inverted filled triangles: cyproheptadine $5 \mathrm{mg} \mathrm{kg}^{-1}$ (see inset). Curves are fits of Equation 1 to the data. Right-hand graph: relation between running response rate and $N$. The curves are fits of Equation 2 to the data; other conventions are as in the left-hand graph.

Figure 2. Effects of clozapine (CLOZ) on progressive-ratio schedule performance. Unfilled circles: vehicle-alone treatment; upright filled triangles: clozapine $3.75 \mathrm{mg} \mathrm{kg}^{-1}$; inverted filled triangles: clozapine $7.5 \mathrm{mg} \mathrm{kg}^{-1}$ (see inset). Other conventions are as in Fig. 1.

Figure 3. Effects of haloperidol (HAL) on progressive-ratio schedule performance. Unfilled circles: vehicle-alone treatment; upright filled triangles: haloperidol $0.05 \mathrm{mg} \mathrm{kg}^{-1}$; inverted filled triangles: haloperidol $0.1 \mathrm{mg} \mathrm{kg}^{-1}$ (see inset). Other conventions are as in Fig. 1.

Figure 4. Effects of chlordiazepoxide (CDP) on progressive-ratio schedule performance. Unfilled circles: vehicle-alone treatment; upright filled triangles: chlordiadepoxide $3 \mathrm{mg}$ $\mathrm{kg}^{-1}$; inverted filled triangles: chlordiazepoxide $10 \mathrm{mg} \mathrm{kg}^{-1}$ (see inset). Other conventions are as in Fig. 1.

Figure 5. Effects of $\Delta^{9}$-tetrahydrocannabinol (THC) on progressive-ratio schedule performance. Unfilled circles: vehicle-alone treatment; upright filled triangles: THC $1 \mathrm{mg}$ $\mathrm{kg}^{-1}$; inverted filled triangles: THC $3 \mathrm{mg} \mathrm{kg}^{-1}$ (see inset). Other conventions are as in Fig. 1. 


\section{CYPROHEPTADINE}

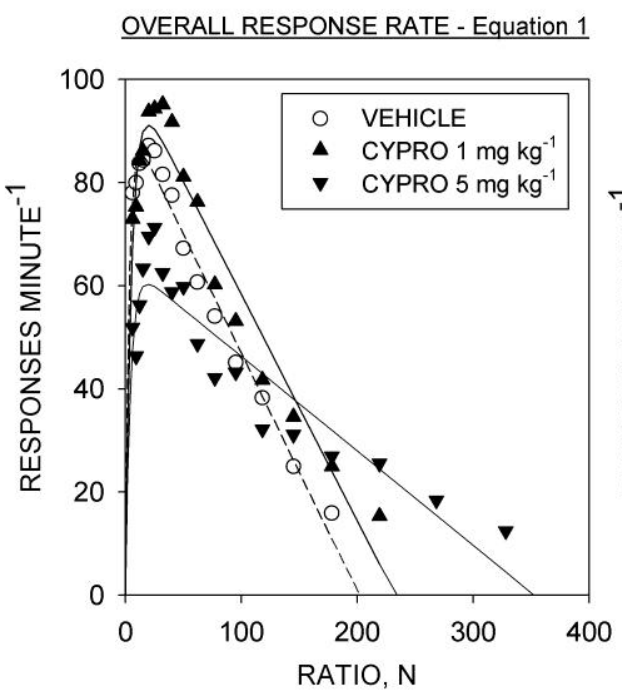

RUNNING RESPONSE RATE - Equation 2

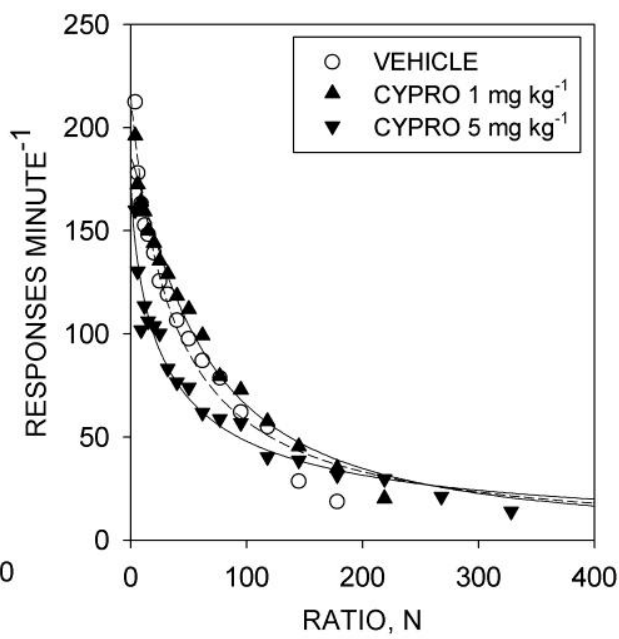

Fig. 1

\section{CLOZAPINE}

OVERALL RESPONSE RATE - Equation 1

RUNNING RESPONSE RATE - Equation 2
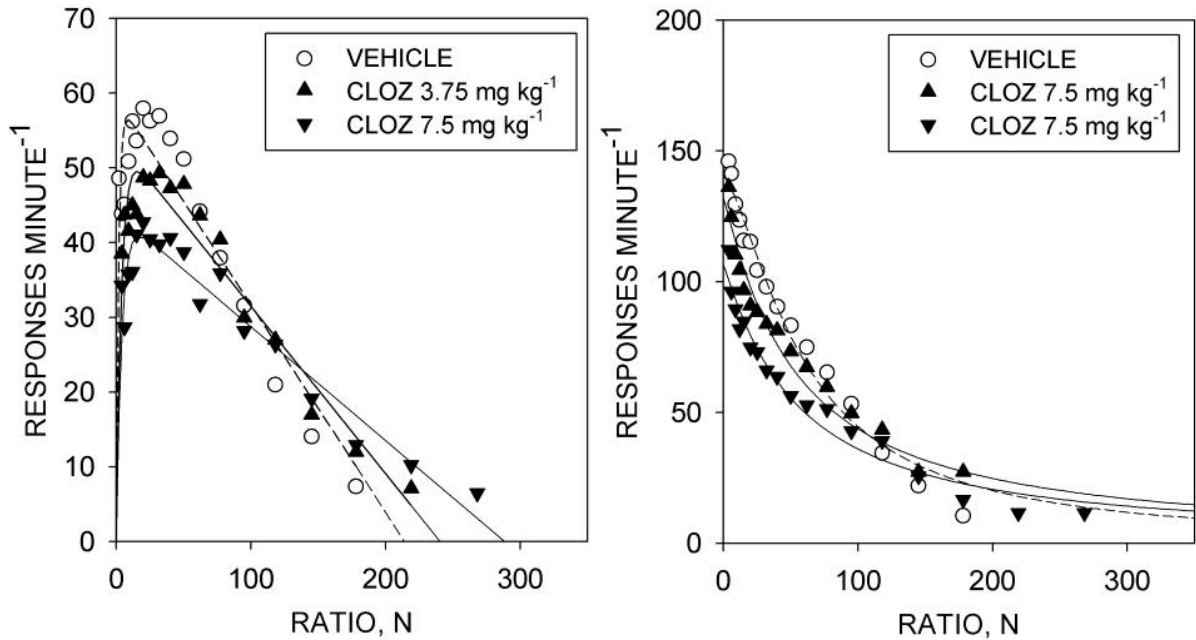

Fig. 2 
HALOPERIDOL

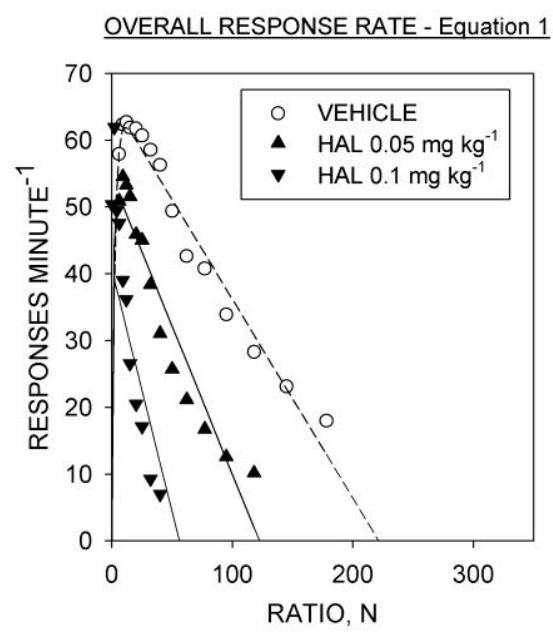

RUNNING RESPONSE RATE - Equation 2

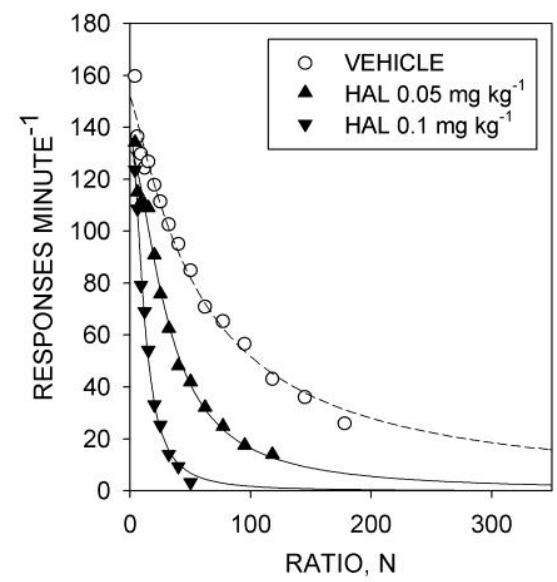

Fig 3

\section{CHLORDIAZEPOXIDE}

OVERALL RESPONSE RATE - Equation $1 \quad$ RUNNING RESPONSE RATE - Equation 2
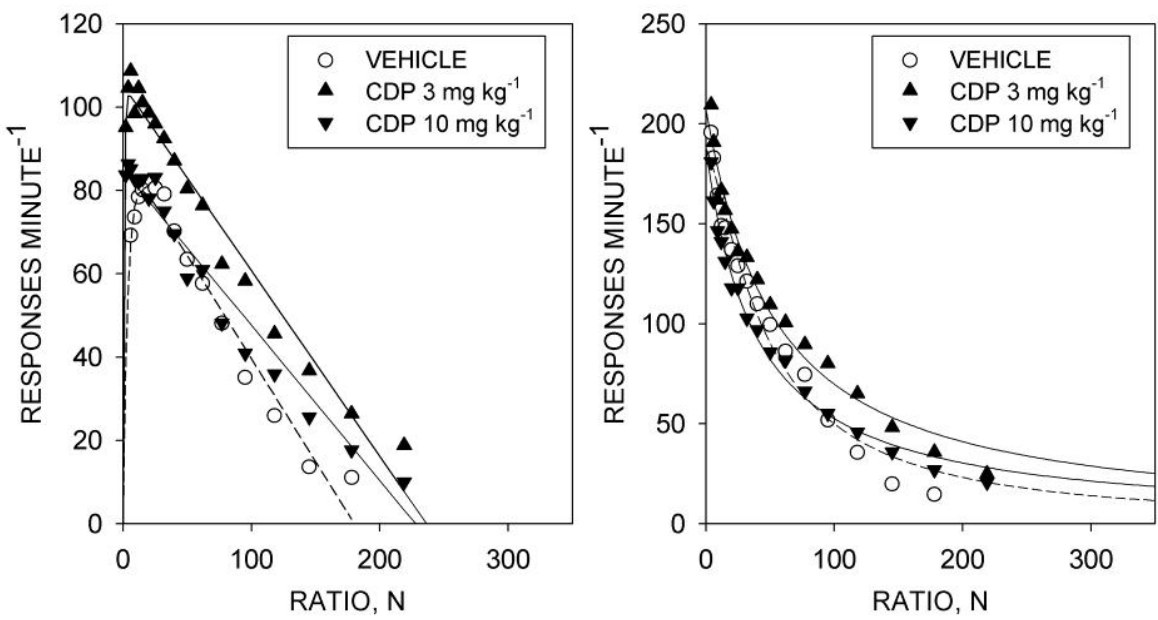

Fig. 4 


\section{$\Delta^{9}$-TETRAHYDROCANNABINOL}

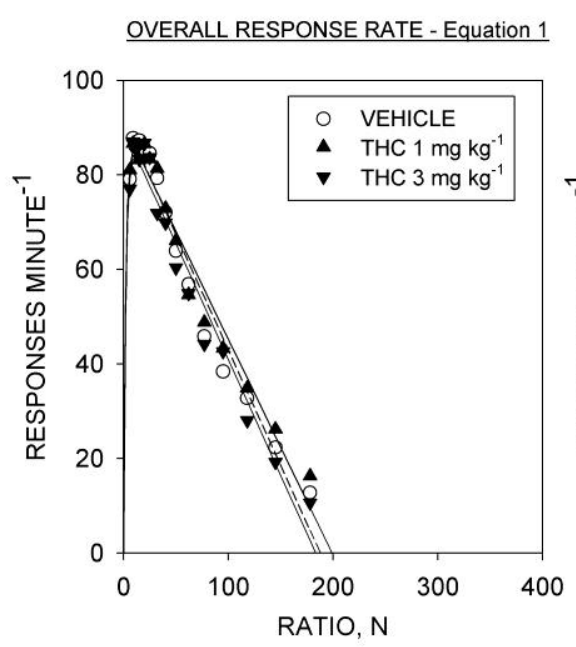

RUNNING RESPONSE RATE - Equation 2

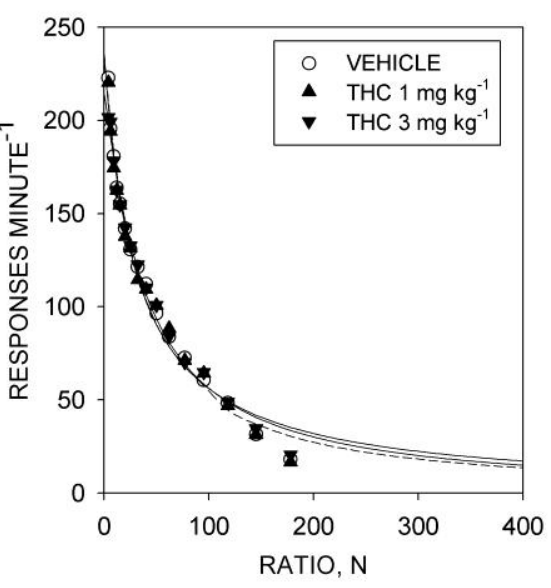

Fig. 5 